\title{
Nitrogen responses on pastures in the southern South Island of New Zealand
}

\author{
L.C. SMITH ${ }^{1}$, J.D. MORTON ${ }^{2}$, W.D. CATTO ${ }^{3}$ and K.D. TRAINOR ${ }^{4}$ \\ ${ }^{1}$ AgResearch, Woodlands Research Station, RD1, Invercargill \\ ${ }^{2}$ AgResearch, Invermay Agricultural Centre, PB 50034, Mosgiel \\ ${ }^{3}$ Southfert Ltd, PO Box 845, Invercargill \\ ${ }^{4}$ AgResearch, PO Box 228, Alexandra \\ ${ }^{1}$ smithc@agresearch.cri.nz
}

\begin{abstract}
In Southern New Zealand, the main limitation to increasing farm production is the low pasture production in early spring and late autumn. In order to accurately predict the effect of nitrogen $(\mathrm{N})$ fertiliser on production at these times, four smallplot mowing trials looking at pasture responses to $\mathrm{N}$ fertiliser were established on two dairy farms and one sheep farm in Southland and one sheep farm in Central Otago in August 1998. Monthly applications of $50 \mathrm{~kg} \mathrm{~N} / \mathrm{ha}$ as urea were applied from August to May. Pasture production was measured monthly using a pasture probe in Southland and by cutting and drying the herbage in Central Otago. Results show that the AugustSeptember applications of $\mathrm{N}$ gave pasture responses of $1.5-9 \mathrm{~kg} \mathrm{DM} / \mathrm{kg} \mathrm{N}$ in 1998 and 6-23 kg DM/kg $\mathrm{N}$ in 1999. The October-November $\mathrm{N}$ applications gave responses of 4-20 kg DM/kg N in 1998 and $4-15 \mathrm{~kg} \mathrm{DM} / \mathrm{kg} \mathrm{N}$ in 1999. The February-March applications of $\mathrm{N}$ produced responses of $6-14 \mathrm{~kg}$ $\mathrm{DM} / \mathrm{kg} \mathrm{N}$ in 1999 and 3.2-20 kg DM/kg N in 2000.

The response to August-applied N was similar in the second month after application to the first month. For the March application, most of the response occurred in the first 30 days following application, although small responses were measured up to 90 days after application at some sites. $\mathrm{N}$ applied in May had a small carryover effect on spring (September) pasture production, but the August application resulted in the greatest overall production increase in September. This study showed that a single application of $\mathrm{N}$ in August or March can result in large pasture production increases under mowing with clippings removed, without depressing clover growth.
\end{abstract}

Keywords: autumn, nitrogen fertiliser, nitrogen response, pasture production, spring

\section{Introduction}

In Southland and Otago, the main limitation to increasing pasture production on farms is the low production in early spring and late autumn. Hence strategic applications of nitrogen fertiliser are commonly used on southern dairy farms, as well as high-producing sheep farms, to extend the pasture growth at the start and end of the growing seasons.

Risk (1982) found that spring applications of $\mathrm{N}$ to southern sheep pastures gave $3-15 \mathrm{~kg} \mathrm{DM} / \mathrm{kg}$ applied $\mathrm{N}$ over 30-40 days growth. However, applications of $\mathrm{N}$ in early August resulted in little pasture response in the first 30 days compared with later applications, mainly owing to climatic factors restricting grass growth and hence its ability to utilise the applied N. For this reason, the present recommendation for Southland is for $10 \mathrm{~cm}$ soil temperatures to reach $5^{\circ} \mathrm{C}$ before $\mathrm{N}$ is applied.

Autumn responses to $\mathrm{N}$ were more variable and lower than spring responses (Risk 1982; Feyter et al. 1985). In these studies, it was possible that the autumn responses were suppressed by $\mathrm{N}$ mineralisation facilitated by favourable soil temperatures. The likelihood of summer/autumn $\mathrm{N}$ responses may be greater in Southland, with its cooler summers, than reported in Waikato dairy pastures by Feyter et al. (1985).

Few studies have been conducted on the use of $\mathrm{N}$ for increasing seasonal pasture production on farms in the south of the South Island. This paper reports on 18 months data from four trials in Southland and Central Otago describing the size, duration and seasonality of pasture $\mathrm{N}$ responses at these sites.

\section{Methods}

Small plot $(4 \mathrm{~m} \times 1.5 \mathrm{~m})$ trials were established in August 1998 on four farms: two dairy farms, one sheep farm in Southland and one sheep farm in Central Otago. The sites were chosen to be representative of the district in terms of pasture and fertility (Table 1).

Fifty $\mathrm{kg} \mathrm{N} / \mathrm{ha}$ was applied as urea each month from August to May to previously untreated plots and responses compared with a single control (no N) plot. The plots were randomised within a block, with each site consisting of four such randomised blocks. In the second year, the same plots were reused for each monthly application. Applications were made about 
Table 1 Trial site locations, soil types and fertility levels (0-75mm) (March 1999).

\begin{tabular}{|c|c|c|c|c|c|c|c|c|}
\hline Site & Farm type & Location & Soil type ${ }^{(1)}$ & Soil group ${ }^{(2)}$ & $\mathrm{pH}$ & $\mathrm{K}$ & $\mathrm{P}$ & $\mathrm{S}$ \\
\hline 1 & Dairy & Tuturau, Southland & Mataura Recent & Recent & 6.2 & 3 & 36 & 17 \\
\hline 2 & Dairy & Oreti, Southland & Drummond YBE intergrade & Brown & 6.0 & 8 & 46 & 9 \\
\hline 3 & Sheep & Gummies Bush, Southland & Waikiwi YBE & Typic firm brown & 5.9 & 5 & 26 & 7 \\
\hline 4 & Sheep & Tarras, Central Otago & Dublin upland YBE & Brown & 5.9 & 14 & 13 & 12 \\
\hline
\end{tabular}

the middle of each month immediately following removal of the existing herbage.

Pasture production was not limited by other nutrients; basal P $(50 \mathrm{~kg} / \mathrm{ha}$ as monocalcium phosphate $)$ was applied annually, while $30 \mathrm{~kg} \mathrm{~S} / \mathrm{ha}$ as gypsum was applied at 6-monthly intervals. Also, a trace element mix containing $200 \mathrm{~g} / \mathrm{ha}$ sodium molybdate, $30 \mathrm{~kg} / \mathrm{ha}$ calcined magnesite, $10 \mathrm{~kg} / \mathrm{ha}$ zinc sulphate, $10 \mathrm{~kg} / \mathrm{ha}$ copper sulphate and $11.25 \mathrm{~kg} / \mathrm{ha}$ sodium tetraborate was applied at the start of the trial. Potassium fertiliser (50 kg K/ha/application) as $\mathrm{KCl}$ was applied every 23 months (August, November, January, and March).

Pasture production was estimated at monthly intervals (September 1998 to May 2000) with the plot yields assessed in Southland by means of a pasture probe measuring the pre- and post-trimming pasture biomass on the plots. After trimming, clippings were removed, leaving a biomass of approximately 1400 $1600 \mathrm{~kg} \mathrm{DM} / \mathrm{ha}$. The Central Otago site was measured by mowing a strip from each plot, weighing the herbage and calculating the DM content from a dried subsample.

In periods of extreme growth at two sites, during spring at Tuturau and spring and mid summer at Tarras, extra cuts prevented the clover in the herbage being shaded out by the grasses.

Pasture samples were hand-cut from all plots at each site in February 1999 and in February 2000 to measure pasture botanical composition. These samples were separated into grass, clover, weeds, and dead material.

The $\mathrm{N}$ use efficiencies $(\mathrm{kg} \mathrm{DM} / \mathrm{kg} \mathrm{N})$ were calculated by combining the production increase over two-monthly measurement periods. The exceptions to this were for the January 1999 application which used 3 months owing to drought conditions through February, and the April and May applications where responses lasted through to the following spring. In several cases, the third and fourth monthly measurement period following $\mathrm{N}$ application produced a negative response, which if included in the calculations resulted in considerably lower $\mathrm{N}$ use efficiencies.

\section{Results}

\section{Production}

Pasture production in year 1 was $10.3 \mathrm{t} \mathrm{DM} / \mathrm{ha}$ at Gummies Bush, $9.4 \mathrm{t} \mathrm{DM} / \mathrm{ha}$ at Oreti, $10.8 \mathrm{t} \mathrm{DM} / \mathrm{ha}$ at Tuturau, and $13.8 \mathrm{t} \mathrm{DM} / \mathrm{ha}$ at Tarras. In year 2 , the figures were $7.9 \mathrm{t} \mathrm{DM} / \mathrm{ha}$ at Gummies Bush, $10.7 \mathrm{t}$ $\mathrm{DM} / \mathrm{ha}$ at Oreti, $11.0 \mathrm{t} \mathrm{DM} / \mathrm{ha}$ at Tuturau and $12.4 \mathrm{t}$ DM/ha at Tarras. The low production at the Gummies Bush site in year 2 was owing to a severe grass grub (Costelytra zealandica) infestation.

\section{$\mathrm{N}$ use efficiency}

Pasture growth responses from the August-September applications averaged $6 \mathrm{~kg}$ (SE 2.4) DM/kg N, and ranged from 1.5-9 kg DM/kg N in 1998, and from 6$23 \mathrm{~kg} \mathrm{DM} / \mathrm{kg} \mathrm{N}$ in 1999 (Figure 1). Responses from the October-November applications averaged 10 (SE 1.6) $\mathrm{kg} \mathrm{DM} / \mathrm{kg} \mathrm{N}$ and ranged from $4-20 \mathrm{~kg} \mathrm{DM} / \mathrm{kg} \mathrm{N}$ for 1998 and from $4-15 \mathrm{~kg} \mathrm{DM} / \mathrm{kg} \mathrm{N}$ in 1999. Responses from the February-March applications averaged 9 (SE 2.8) $\mathrm{kg} \mathrm{DM} / \mathrm{kg} \mathrm{N}$ and ranged from 6$14 \mathrm{~kg} \mathrm{DM} / \mathrm{kg} \mathrm{N}$ in 1999 and from 3-20 kg DM/kg N in 2000 .

\section{Response pattern}

The August application resulted in similar or greater responses in the second month after application at three of the four sites (Figure 2). However, in the third and fourth months the responses were negligible, and even negative at some sites.

For the March application (Figure 3), the majority of the $\mathrm{N}$ response occurred in the first 30 days with smaller responses being measured 30-90 days after application.

\section{Clover content}

The effect of $\mathrm{N}$ application on clover content was measured in February each year, (Table 2). There was no significant depression of clover where $\mathrm{N}$ had been applied. There was an overall decline however, in clover at the Gummies Bush site, due mainly to a severe grass grub infestation in the 1999-2000 year. 


\section{Autumn v spring application}

The mean responses (Figure 4) indicated that a carryover effect from the May application extended as far as October. However, the August application resulted in the greatest overall production increase in September.

\section{Discussion}

Variations between the sites in terms of $\mathrm{N}$ use efficiency were not entirely unexpected, owing to the recorded variation in pasture growth at different sites within Southland (Cossens 1990). Also, the within-site, inter-seasonal variation was to be expected as Harris et al. (1973) noted that a mild dry winter resulted in higher $\mathrm{N}$ responses in spring when compared with a colder wet winter. This factor may explain the greater $\mathrm{N}$ efficiency measured in 1999 compared to 1998 , as the winter of 1999 was particularly mild.

The between-site variation, especially in early spring, could not be tied down purely to soil temperature differences. A possible explanation is the relatively high $\mathrm{N}$ mineralisation rates in spring, this being an important factor for plant N uptake (Carran 1978). Indeed, $\mathrm{N}$ mineralisation figures measured at another trial in Southland show that $\mathrm{N}$ mineralisation rates increase from $0.46 \mu \mathrm{g} \mathrm{N} / \mathrm{g} /$ day in July to $1.58 \mu \mathrm{g} \mathrm{N} / \mathrm{g} /$ day in August and September and peaking at $4.11 \mu \mathrm{g} \mathrm{N} / \mathrm{g} /$ day in October (R. Monaghan unpublished data). Also, when the rainfall in early spring is greater than required by plants, the nitrate- $\mathrm{N}$ in the soil is either leached (Field et al. 1985) or becomes denitrified (Aulakh et al. 1992). The former process is the most likely owing to the relatively low soil temperatures experienced during the spring.

The use of late spring-early summer $\mathrm{N}$ has been suggested as a method of increasing summer milksolid (MS) production (Shaw et al. 1997). However, the limitation of this method is the difficulty of utilising the extra feed produced. In Southland, with its plateau of maximum pasture production from
Figure 1 Efficiency of $\mathrm{N}$ application ( $\mathrm{kg} \mathrm{DM} / \mathrm{kg} \mathrm{N}$ applied) measured over 2 months at four sites. Bars are SEMs.
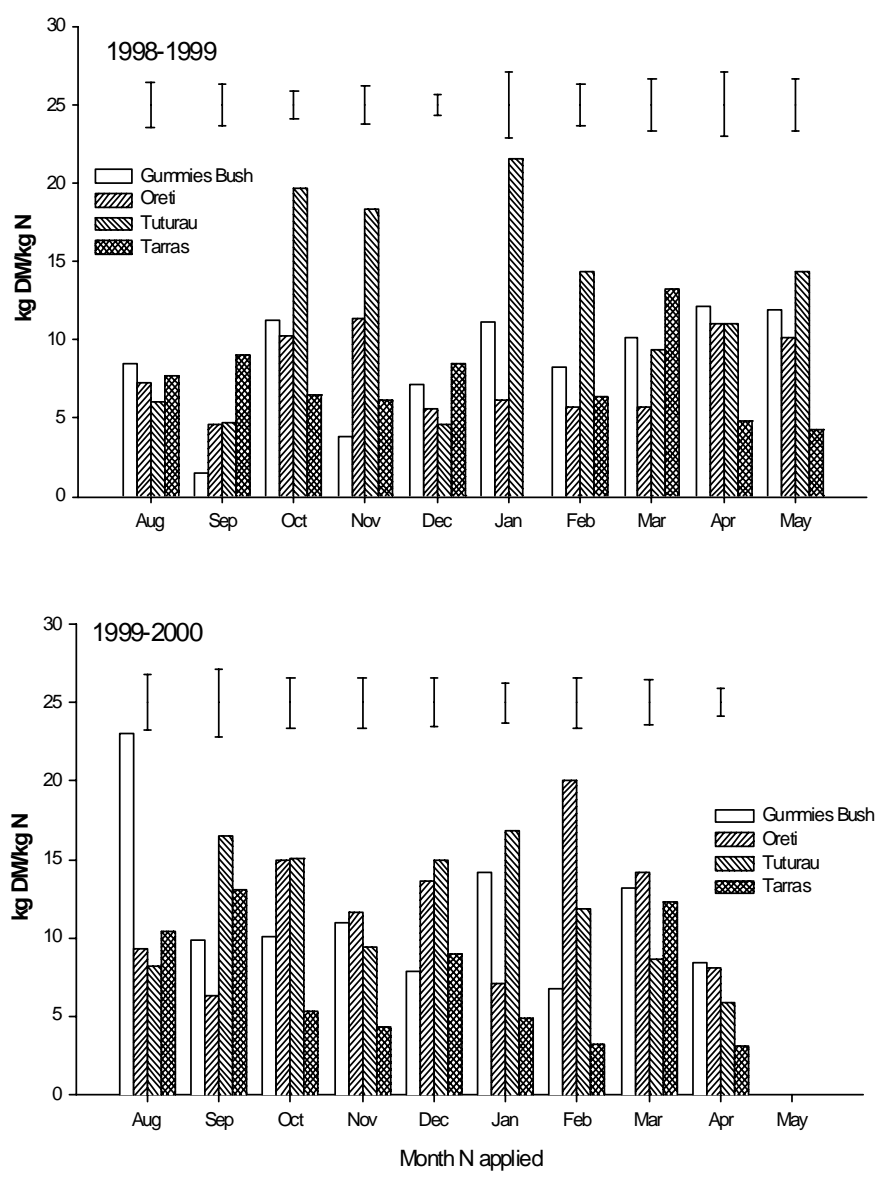

Figure 2 Duration and size of response to $\mathrm{N}$ applied in mid-August at four sites. Bars are SEMs

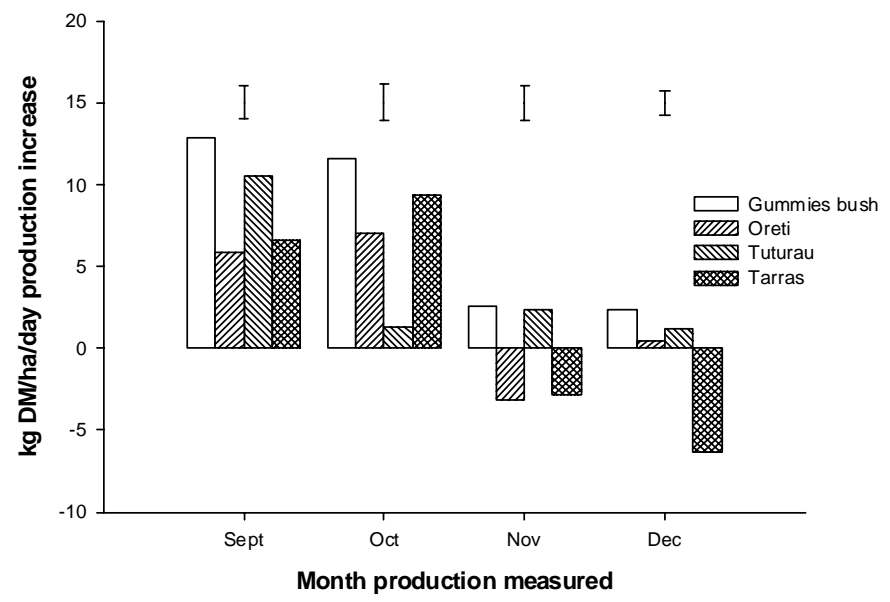


late October to early March (Cossens 1990), a more attractive alternative would be to extend the season in the autumn. As March-applied N resulted in increased pasture growth through to May and June (Figure 3), this has the effect of allowing an extra rotation at the tail of the season (Kleyngeld 1992).

The application of $\mathrm{N}$ in April or May resulted in increased winter and early spring production (Figure 4), but this practice has limitations. Increased nitrate leaching in winter from residual $\mathrm{N}$ fertiliser is especially relevant to the May application, as plant uptake in a normal year would then be low and the leaching potential high (Ledgard et al. 1997). Indeed, leaching data from another Southland trial show that in late autumn, the excretal $\mathrm{N}$ levels in the soil are high but by the spring they are low (R. Monaghan pers. comm.). The necessity of limiting $\mathrm{N}$ use in times of high leaching potential means that the application of $\mathrm{N}$ in late winter (August) to obtain a production increase in early spring is likely to be the more sustainable option.

For farmers, one of the unwanted side effects of $\mathrm{N}$ fertiliser use has been the perceived depression of clover. Feyter et al. (1985) concluded that $\mathrm{N}$ application depressed the clover content of dairy pastures, with this depression being blamed for causing postresponsive reductions in pasture production. While we measured the post responsive reduction (Figures 2 and 3), we did not measure any significant depression in clover content. However, in another Southland grazing trial, where $\mathrm{N}$ was applied to the same area in spring and autumn, clover was significantly depressed (R. Monaghan pers. comm.). It is possible that we have underestimated the effect of $\mathrm{N}$ on clover
Figure 3 Duration and size of response to $\mathrm{N}$ applied in mid-March at four sites. Bars are SEMs

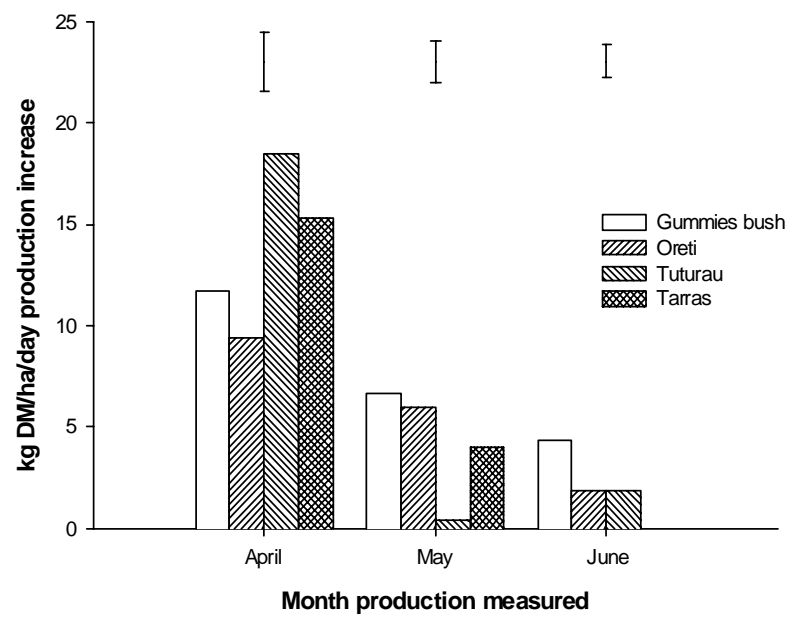

Figure 4 Average spring pasture production from four sites after autumnand winter-applied N. Bars are LSD (5\%).

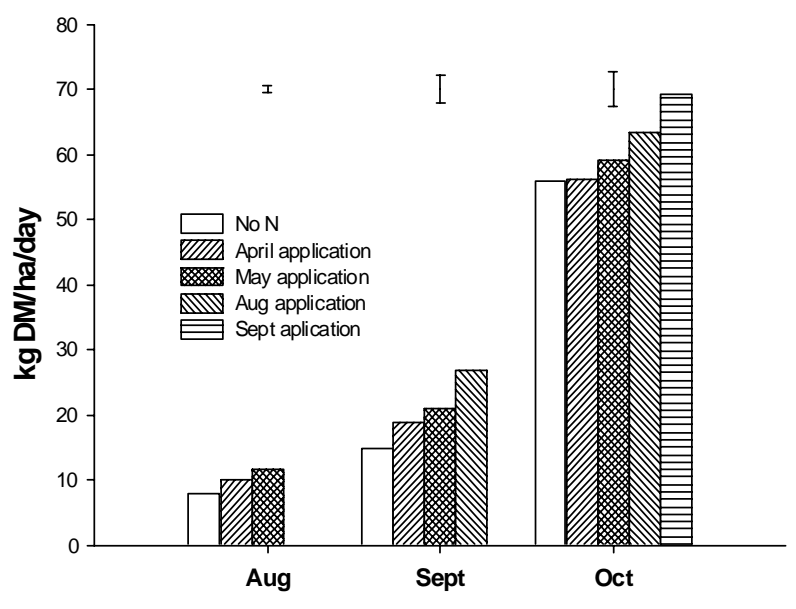

Month production measured

Table 2 Effect of monthly $\mathrm{N}$ application on clover content (\% present) from the four sites as measured in February each year.

\begin{tabular}{|c|c|c|c|c|c|c|c|c|c|}
\hline \multirow[b]{2}{*}{$\begin{array}{l}\text { Month N } \\
\text { applied }\end{array}$} & \multirow{2}{*}{ Tuturau } & \multicolumn{2}{|c|}{ Measured February $1999^{1}$} & \multirow[b]{2}{*}{ Tarras } & \multirow[b]{2}{*}{$\begin{array}{l}\text { Month N } \\
\text { applied }\end{array}$} & \multirow{2}{*}{ Tuturau } & \multicolumn{2}{|c|}{ Measured February 2000} & \multirow[b]{2}{*}{ Tarras } \\
\hline & & Oreti & $\begin{array}{c}\text { Gummies } \\
\text { Bush }\end{array}$ & & & & Oreti & $\begin{array}{c}\text { Gummies } \\
\text { Bush }\end{array}$ & \\
\hline $\begin{array}{l}\text { No N } \\
\text { Aug. } 1998 \\
\text { Sept. } 1998 \\
\text { Oct. } 1998 \\
\text { Nov. } 1998 \\
\text { Dec. } 1998 \\
\text { Jan. } 1999\end{array}$ & $\begin{array}{l}55.6 \\
68.2 \\
62.7 \\
71.7 \\
64.2 \\
59.0 \\
50.9\end{array}$ & $\begin{array}{l}56.3 \\
55.2 \\
41.1 \\
51.9 \\
41.9 \\
48.2 \\
60.3\end{array}$ & $\begin{array}{l}70.7 \\
67.8 \\
46.6 \\
54.8 \\
53.0 \\
50.1 \\
49.1\end{array}$ & $\begin{array}{l}36.9 \\
32.4 \\
21.3 \\
35.2 \\
22.9 \\
30.6 \\
25.4\end{array}$ & $\begin{array}{c}\text { No N } \\
\text { Feb. } 1999 \\
\text { March } 1999 \\
\text { April } 1999 \\
\text { May } 1999 \\
\text { Aug. } 1999 \\
\text { Sept. } 1999 \\
\text { Oct. } 1999 \\
\text { Nov. } 1999 \\
\text { Dec. } 1999 \\
\text { Jan. } 2000\end{array}$ & $\begin{array}{l}37.2 \\
55.2 \\
43.0 \\
48.9 \\
37.7 \\
37.4 \\
42.4 \\
47.1 \\
28.2 \\
32.2 \\
37.0\end{array}$ & $\begin{array}{l}55.3 \\
55.6 \\
60.2 \\
70.3 \\
60.5 \\
63.9 \\
59.1 \\
54.8 \\
53.6 \\
53.3 \\
41.8\end{array}$ & \begin{tabular}{r|}
13.7 \\
3.3 \\
7.3 \\
3.8 \\
2.8 \\
0.0 \\
5.0 \\
4.5 \\
5.8 \\
0.2 \\
0.8
\end{tabular} & $\begin{array}{l}38.8 \\
40.3 \\
41.3 \\
40.3 \\
40.4 \\
34.8 \\
47.0 \\
36.9 \\
39.6 \\
31.1 \\
31.9\end{array}$ \\
\hline SED & $\begin{array}{c}10.3 \\
\mathrm{~ns}\end{array}$ & $\begin{array}{l}9.1 \\
\mathrm{~ns}\end{array}$ & $\begin{array}{c}9.0 \\
\mathrm{~ns}\end{array}$ & $\begin{array}{c}7.9 \\
\mathrm{~ns}\end{array}$ & & $\begin{array}{c}7.6 \\
\mathrm{~ns}\end{array}$ & $\begin{array}{l}7.9 \\
\text { n s }\end{array}$ & $\begin{array}{l}4.0 \\
\mathrm{~ns}\end{array}$ & $\begin{array}{l}4.8 \\
n s\end{array}$ \\
\hline
\end{tabular}


as all four sites in this study had considerably more clover present than expected, this being a consequence of the mowing and clippings-removed management.

\section{Conclusions}

1. Responses to $\mathbf{N}$ fertiliser in Southland lasted $30-90$ days.

2. August-September application of $\mathrm{N}$ resulted in production increases of $2-23 \mathrm{~kg} \mathrm{DM} / \mathrm{kg} \mathrm{N}$.

3. February-March applications of $\mathrm{N}$ resulted in production increases of 3-20 kg DM/kg N.

4. May application of $\mathrm{N}$ had a small carry-over effect on spring production.

5. August application of $\mathrm{N}$ was more efficient at increasing early spring production than May application.

6. A single application of $\mathrm{N}$ fertiliser had no detrimental effects on the February clover content of pastures.

7. Because these trials were conducted with mowing and clippings-removed management, the effects of $\mathrm{N}$ fertiliser application on depressing clover content and increasing pasture production in grazed pastures may be underestimated.

\section{ACKNOWLEDGEMENTS}

The authors thank the farmers, R. Greer, (Tuturau), J. Kennedy (Oreti), J. Hopcroft (Gummies Bush) and C. Kane (Tarras) for the use of their properties. Also Colleen Wheeler and Beth Henderson for taking the Southland field measurements. We thank Southfert Ltd for funding.

\section{REFERENCES}

Aulakh, M.S.; Doran, J.W.; Mosier, A.R. 1992. Soil denitrification - Significance, measurement, and effects of management. Advances in Soil Science 18: 1-57.
Carran, R.A. 1978. Soil nitrogen and pasture management. Proceedings of the New Zealand Grassland Association 40: 44-50.

Cossens, G.G. 1990. Pasture and Lucerne production in Otago and Southland 1950 to 1987. Invermay Technical Report No 21, M.A.F. Invermay

Feyter, C.; O'Connor, M.B.; Addison, B. 1985. Effects of rates and times of nitrogen application on the production and composition of dairy pastures in Waikato district, New Zealand. New Zealand Journal of Experimental Agriculture 13: 247-252.

Field, T.R.O.; Roger Ball, P.; Theobald, P. W. 1985. Leaching of nitrate from sheep-grazed pastures. Proceedings of the New Zealand Grassland Association 46: 209-214.

Harris, A.J.; Brown, K.R.; Turner, J.D.; Johnston, J.M.; Ryan, D.L.; Hickey, M.J. 1973. Some factors affecting pasture growth in Southland. New Zealand Journal of Experimental Agriculture 1: 139-163.

Hewitt, A.E. 1998. New Zealand Soil Classification. Landcare Research science series 1. Manaaki Whenua Press, Lincoln, Canterbury, New Zealand.

Kleyngeld, M.; Kleyngeld, I. 1992. Conversions of an eastern Southland sheep farm to factory supply dairy pasture: changes and implications for production. Proceedings of the New Zealand Grassland Association 54: 15-17.

Ledgard, S.F.; Penno, J.W.; Sprosen, M.S. 1997. Nitrogen balances and losses on intensive dairy farms. Proceedings of the New Zealand Grassland Association 59: 49-53.

Risk, W.H. 1982. The use of nitrogen fertilisers on the Southland plains. pp. 149-158. In: Nitrogen fertilisers in New Zealand agriculture. Ed. P.B. Lynch. New Zealand Institute of Agricultural Science, Wellington.

Shaw, R.J.; Thomson, N.A.; McGrath, D.F.; Dawson, J.E. 1997. More summer milk - an on-farm demonstration of research principles. Proceedings of the New Zealand Grassland Association 59: 149-155. 
